\title{
LETTERS AND FURTHER COMMENTARY \&
}

May 10, 1983

Dear Sir:

After reading Glendon Schubert's "The Evolution of Political Science: Paradigms of Physics, Biology, and Politics" and the commentaries on the Schubert article by Hayward Alker and Dina Zinnes (Politics and the Life Sciences 1:97-124), it became obvious that the real topic of concern in the Schubert article and in the commentaries was not political science, physics, or biology per se-or their interrelatedness - but the ethics of belief.

For those political scientists who believe improvement in natural order to be the main attribute of human institutions and actions one can hypothesize that "normal" political science will be the mode in which truth will be sought after. On the other hand, for those political scientists who believe human institutions are a necessary encroachment on the natural order-although not necessarily beneficialone can hypothesize that the search for truth will be done via biopolitics. For example, the "normal" political scientist may argue that war is bad and medicine that saves lives is good; the biopolitical scientist may view war as wholesale killing, medicine as indiscriminate saving of lives, and neither as having much to do with an evolutionary stable strategy.

Biopolitics makes sense because biology is an integrating science: life itself is a phenomenon that all known principles of science apply to. In its broadest sense biopolitics is the study of the positive and negative effects of science and technology on society and its aim is to promote the survival of the human species and enhance the adaptability of political institutions.

Sincerely,

David L. Keys

Research Associate

Advanced Studies in Science,

Technology, and Public Policy

Indiana University
Political Psychology and Biopolitics Revisited: A Rejoinder

Political Psychology and Biopolitics tried to do two things: provide a brief survey of the landscape of a fairly new field of inquiry (the marriage of psychological and biopolitical theories and indicators with foreign policy analysis) and illustrate one specific research program in this area, my adaptation and application of Milton Rokeach's work on value systems to foreign policy elites in almost 40 countries for the period from 1966 to 1970 . I would be the first to admit that the value results were "interesting but only mildly persuasive."1 The field itself remains both promising and immature, although we can perhaps discern a little progress (see, for example, the essays in Hopple, 1982).

Some years ago, Bruce Russett (1969) responded to an intemperate and perfectionistic critic of his research in what was then the new field of quantitative international politics by referring to the "young science of international politics." I am unaware of (or at least unfamiliar with) any research conducted by any of my three reviewers in the area of biopolitics, political psychology, and foreign policy. As one who knows the field from the inside, I am perhaps unduly impressed by what I perceive to be some progress and, in a few cases, genuine excitement about what is going on. But I hasten to add that this new hybrid field, which meshes individual (biopolitical and psychological) phenomena with foreign policy phenomena, is a very young science indeed.

Joseph V. Montville's review perplexes me. Six of the eleven paragraphs have nothing to do with my book. Montville serves up another discussion of "research and relevance." Dozens of academics, practitioners, and individuals in nonacademic research organizations have defined, debated, refined, reviewed, and pontificated on the subject of relevant research, and they have been doing all of the above for decades. Montville does quite a bit of pontificating, but he adds nothing to the voluminous literature

POLITICS AND THE LIFE SCIENCES, Vol. 2, No. 1, August 1983. ISSN 0730-9384. ๑ 1983 by the Association for Politics and the Life Sciences. 